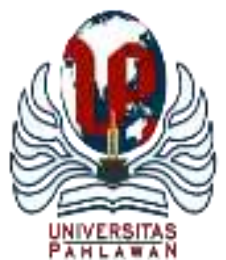

\title{
JURNALBASICEDU
}

Volume 6 Nomor 1 Tahun 2022 Halaman 675 - 683

Research \& Learningin Elementary Education

https://jbasic.org/index.php/basicedu

\section{Model-Model Evaluasi Pendidikan dan Model Sepuluh Langkah dalam Penilaian}

\author{
Meila Yufriana Devi ${ }^{1 凶}$, Rahma hidayanthi ${ }^{2}$, Yanti Fitria ${ }^{3}$ \\ Universitas Negeri Padang, Indonesia ${ }^{1,2,3}$ \\ E-mail: $\underline{\text { meilayufrianadevi1@ gmail.com }}{ }^{1}, \underline{\text { rahmahidayanthi712@gmail.com }}^{2}$, yanti fitria@ fip.unp.ac.id ${ }^{3}$
}

\begin{abstract}
Abstrak
Dalam penyelenggaraan pendidikan tidak terlepas dari pola atau model evaluasi pendidikan guna untuk melakukan evaluasi yaang sesuai dengan aturan yang telah ditetapkan dalam suatu model pendidikan. Penelitian ini bertujuan untuk mengekprolasi serta eenganalisis tentang pentingnya kompetensi guru dalam melakukan evaluasi berdasarkan model-model pendidikan yang ada, dengan model-model evaluasi nantinya guru akan lebih mudah untuk menyesuaikan model evauasi deengan karakteristik pesertaa didik agar evaluasi yang dilakukan menjadi lebih baik. Metode penelitian ini menggunakan jenis penelitian studi kepustakaan (library research) dengan pendekatan eenelitian deskriptif kualitatif. Hasil Penelitian ini adalah terdapat empat model-model evaluasi pendidikan yaitu (1) Goal Oriented Evaluation, (2) Goal Free Evaluation, (3) Formatif Sumatif Evaluation, (4) Countenance Evaluation. Terdapat model sepuluh langkah dalam penilaian pendidikan yang tertuang dalam buku Tenbrink. Sebagai program instruktif memerlukan penilaian untuk memeriksa apakah tujuan yang diatur program dapat diketahui. Beberapa hal yang harus diketahui tentang siswa seperti guru harus melakukan evaluasi setelah selesai melakukan pembelajaran agar nantinya guru bisa mengukur sejauh mana keberhasilan pembelajaran yang telah guru lakukan.
\end{abstract}

Kata Kunci: Model-model evaluasi, Pendidikan, Model sepuluh langkah.

\section{Abstract}

The implementation of education cannot bee separated from the pattern or model of educational evaluation in order to carry out evaluations in accordance with the rules that have been set in an educational model. This study aims to explore or analyze the importance of teacher competence in conducting evaluations based on existing educational models, With evaluation models, the teacher will later find it easier to adjust the evaluation model to the characteristics of the students so that the evaluation will be better. This research method uses a type of library research with a qualitative descriptive research approach. The results of this study are thaat there are four educational evaluation models, namely (1) Goal Oriented Evaluatiion, (2) Goal Free Evaluation, (3) Formative Summative Evaluation, (4) Countenance Evaluaation. There is a ten-step model in educational assessment contained in Tenbrink's book. As an instructive program it requires an assessment to check whether the objectives set by the program are known. Some things that must be known about students such as teachers muust evaluate after completing learning so that later the teacher can meeasure thee exteent too whiich thee succeess oof thee leearning that the teacher has done.

Keywords: Evaluation models, Education, Ten-step models

Copyright (c) 2022 Meila Yufriana Devi, Rahma hidayanthi, Yanti Fitria

$\triangle$ Corresponding author :

Email : meilayufrianadevi1@gmail.com

DOI $\quad:$ https://doi.org/10.31004/basicedu.v6i1.1934

ISSN 2580-3735 (Media Cetak)

ISSN 2580-1147 (Media Online) 


\section{PENDAHULUAN}

Rencana pendidikan, siklus belajar, dan penilaian adalah bagian penting dalam program pembelajaran meskipun bagian yang berbeda. Bagian-bagian ini diidentifikasi satu sama lain. Rencana pendidikan tersebut berisi Standar Kompetensi dasar dan Kompetensi yang merupakan pembentukan program pembelajaran. Sistem pembelajaran adalah pekerjaan untuk mencapai kemampuan dasar yang direncanakan dalam program pendidikan (Hamalik 2011).

Berhasil atau tidaknya pendidikan dalam mencapai tujuannya dapat dilihat setelah dilakukan evaluasi terhadap output atau lulusan yang dihasilkannya. Jika output lulusan, hasilnya sesuai dengan apa yang telah digariskan dalam tujuan pendidikan, maka usaha pendidikan itu dapat dinilai berhasil, tetapi jika sebaliknya, maka ia dinilai gagal (Elis Ratna Wulan, Elis and Rusdiana 2015). Dari sisi ini dapat dipahami betapa pentingnya evaluasi pembelajaran dalam proses pendidikan. Maka dari itu evaluasi pembelajaran merupaakan bagian penting dari evaluasi pendidikan pada umumnya. Dalam ruang lingkup terbatas, evaluasi pembelajaran dilakukan dalam rangka mengetahui tingkat keberhasilan peserta didik. Sedangkan dalam ruang lingkup luas, evaluasi pembelajaran dilakukan untuk mengetahui tingkat keberhasilan dan kelemahan suatu proses pembelajaran dalam mencapai tujuan pendidikan yang di cita-citakan. Dalam bidang pendidikan evaluasi pembelajaran merupakan kegitan wajib bagi setiap insan yang berkecimpung dalam bidang pendidikan.

Sebagai seorang pendidik, proses evaluasi pembelajaran berguna dalam hal pengambilan keputusan kedepan demi kemajuan anak didik pada khususnya dan dunia pendidikan pada umumnya. Setiap perbuatan dan tindakan dalam evaluasi pembelajaran selalu menghendaki hasil (Pratiwi Pujiastuti, Sekar Purbarini Kawuryan 2017). Pendidik selalu berharap bahwa hasil yang diperoleh sekarang lebih baik dan memuaskan dari hasil yang diperoleh sebelumnya, untuk menentukan dan membandingkan antara satu hasil dengan lainnya diperluaan adanya evaluasi pembelajaran. Karena penelitian terdahulu hanya membuat beberapa model evaluasi, maka disini lebih dikembangkan lagi model-model penelitian yang ada agar menarik perhatian siswa dalam pembelajaran, adanya teori yang menyatakan bahwa cukup dengan satu model evaluasi saja, namun itu tidak sesuai dengan kenyaataan yag ada di lapangan. Dengan adanya model yang bervariasi menyebabkan anak lebih semangat lagi dalam pembelajaran. Penelitian yang ada sebelumnya hanya membahas satu model evaluasi dan disini akan membuat beberapa model evaluasi. Penelitian ini sangat penting untuk dilakukan agar dapat meningkatkan hasil belajar siswa.

Latihan evaluasi dilakukan untuk mengukur dan mensurvei tingkat pencapaian Kompetensi Dasar (Desi 2002). Evaluasi juga digunakan untuk menemukan kualitas dan kekurangan dalam sistem pembelajaran, sehingga cenderung digunakan sebagai alasan untuk arah, dan pengembangan sistem pembelajaran yang telah selesai. Sejalan dengan ini, program pendidikan yang layak dan proses pembelajaran yang tepat harus ditegakkan oleh kerangka evaluasi yang layak, diatur dan konstan. Penilaian pembelajaran adalah tahap penting dalam sistem pembelajaran yang diselesaikan pada semua tingkat pembelajaran.

\section{METODE PENELITIAN}

Artikel ini disusun menggunakan rencana survei penulisan. Menulis berkonsentrasi pada sarana untuk mengumpulkan data yang berbeda yang terdiri dari buku, artikel logis, dan referensi yang berbeda yang sesuai dengan isu-isu yang diangkat dalam ujian (Siregar et al, 2019). Seluruh sumber perpustakaan kemudian digabungkan, sebagai fitur dari campuran informasi (Yuwono et al, 2021). Menulis studi adalah ulasan yang dibantu melalui berbagai sumber kemudian, pada saat itu, diringkas menjadi laporan total (Fitria, 2021). Pengumpulan data dilakanakan dengan jejak online yaitu menelusuri artikel serta jurnal dengan layanan penyedia jurnal. Penelitian ini di lakukan dengan cara mencari beberapa model yang menarik digunakan 
dalam evaluasi pembelajaran dengan memperhatikan karakteristik dari siswa, dan dengan adanya berbagai model evaluasi menyebabkan anak lebih aktif dalam pembelajarannya.

Hasil analisa dari bermacam jurnal yaang didapat memperlihatkan bahwa model evaluasi pendidikan harus digunakan agar mencapai tujaan pembelajaran dengan baik. Jenis penelitian merupakan kualitatif metode deskriptif. Sebuah langkah penelitian yang memuat data deskriptif (Aprida 2017).Penelitian Kualitatif adalah studi terorganisir untuk menemukan pengetahuan, dan menunjukkan arti masalah (Nizar 2016).

Peserta dari penelitian ini ialah guru yang harus memperhatikan pemberian penilaian kepada siswa dengan memperhatikan model evaluasi yang digunakan dan dapat mengimplementasikannya saat melaakukan penilaian. Data dikumpulkan dari bermacaam jurnal yang relevan dengan bahasan penelitian ini. Kemudian mencari serta mengambil datanya yang terkait untuk agar bisa diperlukan supaya hasilnya benar. Ini diikuti dengan interpretasi untuk menemukan sebuah hasil yang akan membuat tercapai tujuan dari penelitian ini.

Buku yang dibuat analisis sebagai sumber perspektif ulasan ini dari buku cetak dan artikel logis yang diambil para ilmuwan dari peneliti Google dan buku harian web lainnya. Disini juga menggunakan literature dari (Mahmudi 2011) yang menyatakan suatu studi tentang evaluasi pendidikan, dan Islamadina (Darodjat D 2015). jurnal peneliti di atas relevan dengan penelitian yang akan dilakukan kerena itulah peneliti memilih literature dari buku dan beberapa jurnal yang relevan. Informasi yang diproduksi adalah pemikiran baru sebagai informasi seperti realitas, data atau pemikiran mendasar yang diperkenalkan oleh para spesialis sehingga ulasan ini menggunakan kombinasi penulisan informasi penelitian survei (Synder, 2019). Penggabungan informasi pemeriksaan dengan teknik ini untuk penggambaran dengan menangani dan mengumpulkan informasi yang telah dikumpulkan dari tulisan dan efek samping penelitian sebelumnya dengan memadukan atau menyimpulkan informasi.Tolak ukur dari penelitian ini adalah melihat bagaimana kinerja dari model-model pembelajaran yang telah dibuat agar dapat meningkatkan rangsangan kepada siswa dalam mengevaluasi pembelajaran yang ada. Sehingga dapat meningkatkan hasil belajar serta mutu pendidikan sekolah dasar.

\section{HASIL DAN PEMBAHASAN}

Sejumlah jurnal dan artikel dianalisis tentang model-model evaluasi pendidikan dan model sepuluh langkah dalam penilaian.

\section{Model-model Evaluasi Pendidikan}

Secara harfiah kata evaluasi berasal dari bahasa Inggris evaluation; dalam bahasa Arab al-Taqdir; dalam bahasa Indonesia berarti: penilaian. Akar katanya adalah value; dalam bahasa Arab: al-Qimah; yang berarti nilai (Arifin 2014). Apabila disandingkan dengan pendidikan maka evaluasi pendidikan atau educational evaluation merupakan al-Taqdir al-Tarbawiy yang diartikan sebagai penilaian dalam bidang pendidikan atau penilaian mengenai hal-hal yang berkaitan dengan kegiatan pendidikan (Arif 2019). Dari kata evaluation inilah diperoleh kata Indonesia evaluasi yang berarti menilai (tetapi dilakukan dengan mengukur terlebih dahulu).

\section{Goal Oriented Evaluation}

Model ini adalah sebuah model yang tampaknya paling cepat. Sebuah penilaian evaluasi pada penilaian ini adalah alasan untuk eavaluasi yang baik dibentuk beberapa waktu ketika penilaian belum dilakukan. Penilaian selesai tidak berhenti, berkelangsungan ,memevaluasi sebagian dari pertujuan yang selesai dilaksanakan selama waktu yang dihabiskan melaksanakan program (Pratiwi Pujiastuti, Sekar Purbarini Kawuryan 2017). Model ini diciptakan oleh Tyler. Model ini dengan serius menekankan kehadiran siklus penilaian yang secara langsung bergantung pada tujuan pendidikan yang sudah ditentukan bersama-sama sehingga dapat menunjukkan kesiapan, pada saat seseorang instruktur berkomunikasi bersama pelajarnya berubah untuk fokus utama dalam sistem pembelajaran. 
Penilaian pendekatan yang goals oriented telah menstimulasi proses berkembangnya perancangan tujuan secara spesifik serta pengembangan atau penemuan instrumen-instrumen ataupun prosedur pengukuran yang beraneka ragam secara teknologis (rina novalinda, ambiyar 2020).

Goals evaluasi program dalam dunia kependidikan meliputi delapan aspek, yaitu pengajaran, diaagnosis (upaya perbaikan), hasil belajar, fungsi seleksi, penyuluhan (bimbingan), fungsi penempatan, penilaian kelembagaan, dan kurikulum. Evaluasi dari prosess approach ialah untuk mengetahui ketercapaian tujuan pendidikan dan upaya perbaikan serta pengarahan pelaksanaannya. Selanjutnya, kegiatan pendidikan ditinjaau dari pendekatan kelembagaan ialah kegiatan yang meliputi perancangan, design, pembuatan program, setting,pelaksanaan pengawasan, dan penilaian (Rina Novalinda, Ambiyar 2020).

\section{Konsep Pendekatan Evaluasi Berorientasi Tujuan (Goals-Oriented)}

Ralph W Tyler pertama kali memprakarsai pendekatan evaluasi goal-oriented pada tahun 1940-1950an sebaagai tolak ukur terhadap evaluasi pendidikan. Dahulu untuk melakukan evaluasi di dunia pendidikan dilaksanakan melalui instrumen tes dengan memakai dasar kriteria. Tyler memakai sistematika yang lebih lengkap untuk menautkan hasil yang dicapai siswa dengan yang diaambakan. Tyler memformulasikan penilaian hasil belajar dari goal pembelajaran yang didasarkan pada taksonomi yang diuraikan Bloom beserta Krathwohl, yang selajutnya dinamakan orientasi Tyler (Putra 2014).

Dalam perkembangan selanjutnya, orientasi Tyler juga dikembangkan oleh beberapa ahli, seperti Metfessel dan Michael (1967), Hammond (1973), dan Provus (1973). Beberapa pendekatan tersebut memiliki ciri yang sama, yaitu inti evaluasi program tersebut sejauh mana tujuan telah dicapai setelah program dilaksanakan. Evaluasi pendidikan sebagai satu proses bagaimana mendefenisikan pencapaian tujuan/target pendidikan dari kurikulum atau program sekolah (Putra 2014). Evaluasi program goals-oriented Tyler dirancang untuk mendeskripsikan pencapaian tujuan suatu program. Tyler menerapkan kesenjangan antara harapan dan yang teramati sebagai masukan atau pertimbangan pada kekurangan dari kegiatan program orientasi tersebut yang menitik beratkan pada goal khusus suatu kegiatan serta bagimana hasil pencapaiaan program tersebut (Arifin 2014).

Menentukan pencapaian tujuan kegiatan/program pendidikan, Tyler menguraikan beberapa tahap penilaaan pendidikan, yakni penetapan tujuan global atau umum, mengelompokkan/mendeskripsikan sasaran/target, menentukan situasi pencapaian tujuan yang ditetapkan, mengembangkan teknik penilaian, menghimpun serta membandingkan data untuk kerja dengan sikap/karakter yang mendeskripsikan tujuan.

Setelah setiap tahap berakhir, dapat diketahui ketimpangan antara tujuan dan hasil yang diharapkan. Selanjutnya hasil tersebut dipakai sebagai pengoreksi kelemahan program, kemudian pengulangan dapat dilakukan kembali pada tahap tersebut. Pandangan Tyler secara rasional dapat disambut baik dan digunakan oleh para praktisi pendidikan dalam kegiatan evaluasi. Tyler juga menerapkan posttest dan pretest untuk dipakai sebagai instrumen dalam penilaian. Teknik pretest-posttest bertujuan untuk menetapkan perubahan yang berlaku bagi perseorangan, program/kegiatan serta banyaknya perubahan.

Tyler meenguraikan 6 (enam) goals-oriented dari sekolah, yaitu: memperoleh informasi; mengembangkan keterampilan atau kompetensi belajar; membaangun berpikir yang inovatif dan efektif; penanaman perilaku, minat, kepekaan sosial, dan apresiasi; serta menumbuhkan falsafah hidup (makin lama seseorang belajar, maka filosofis hidupnya akan eeningkatkan, dari tidak mengerti menjadi mengerti). Tyler menerangkan pentingnya mencermati aspek sikap dalam mengembangkan tujuan pembelajaran di sekolah. Tyler menegaskan pentingnya filtrasi tujuan umum sebagai dasar untuk melakukan evaluation program. Di bidang pendidikan, cara mengfiltrasinya untuk menyusun pertanyaan-pertanyaan yang berfaedah tentang pedagogis, filsafat maupun sosial (Syarifuddin 2016).

Sisteem peembelajaran seharusnya efektif sesuai dengan pendukung model ini, jika pelajar yang ada dalam situasi sistem belajar akan tercapai sesuai dengan target pendidikan dan pembelajaran. 


\section{Goal Free Evaluation Model}

Penilaian dibuat Michael Scriven bisa dianggap bertentangan sama penilaian utama yang dibuat oleh Tyler, evaluator terus-menerus menyaring tujuan, untuk menjadi spesifik dari awal cara yang paling umum untuk melanjutkan, dalam model penilaian bebas obyektif benar-benar mendapat beberapa jarak dari tujuan. Seperti yang ditunjukkan oleh Mechael Scriven, dalam menyelesaikan penilaian program evaluator tidak ada alasan kuat untuk fokus pada apa motivasi di balik program. Apa yang harus dipertimbangkan pada pembelajaran ini yaitu kinerja penilaian yang membedakan penampilan (Mutiaramses, Mutiaramses, Neviyarni S 2021).

Pembenaran mengapa alasan program tidak boleh dipertimbangkan adalah dengan alasan bahwa ada masuk akal bahwa evaluator terlalu pasti untuk berpikir tentang memperhatikan setiap tujuan tertentu (Syarifuddin 2016). Dengan asumsi setiap objek tertentu. Adapun alasan kenapa tujuan program tidak harus diperhitungkan karena ada taksiran pada evaluator lebih lengkap mengamati setiap tujuan spesifik. Jika setiap tujuan spesifik tercapai, maka akan tercapai penilaian, namun evaluator tertinggal melihat sejauh mana setiap penilaian tersebut mendukung penilaian terakhir yg diperlukan oleh tujuan universal maka hasilnya jumlah penampilan spesifik tidak memiliki banyak faedah.

Dari beberapa penjelasan di atas penulis simpulkan bahwa model evaluasi lepas tujuan dikembangkan oleh Michael Scriven. Model ini bertentangan dengan model yang pertama dimana perbedaan nya terletaka pada orientasi tujuan. Sedangkan Model evaluasi lepas tujuan adalah model yang lepas dari tujuan spesifik, tidak lepas dari tujuan global. Model ini tetap memperkirakan tujuan global dari suatu program (Syarifuddin 2016).

\section{Formatif Sumatif Evaluation Model}

Penilaian perkembangan adalah penilaian menemukan hasil pembelajaran yang dicapai oleh siswa setelah siswa melewati program dalam unit topik dalam suatu bidang studi tertentu (Arikunto 2010). Berbeda dengan penilaian sumatif yaitu penilaian diarahkan pada pembelajaran siswa mengambil ilustrasi Chesswula memutuskan tingkat yang lebih tinggi.

Selain evaluasi yang lepas asal tujuan, Michael Scriven mengenalkan model evaluasi lain, yaitu model formatif-sumatif. Model yang mengambarkan dimaana terdapat tahapan serta ruang objek yang dinilai, yaitu penilaian yang dilaksanakan ketika program berjalan (diklaim sebagai evaluasi formatif) dan saat kegiatan telah selesaai atau berakhir (diklaim sebagai evaluasi sumatif) (Amri 2015).

Tujuan evaluasi formatif sangat tidak selaras dengan evaluasi sumatif. Dengan demikian, model yang dipopulrkan oleh Michael Scriven ini mengarah tentang "apa, kapan, serta tujuan" evaluasi pendidikan tersebut dilaksanakan. Evaluasi formatif adalah evaluasi yang dilaksanakan saat kegiatan masih berlangsung (Kunandar 2013). Tujuan evaluasi formatif ialah agar mengetahui sejauh mana program yang didesain dapat berjalan, dan bisa mengiidentifikasi kendala yang mungkin terjadi. Dengan diketahuinya kendala dan hal-hal yang mengakibatkan program tidak berjalan, pengambilan keputusan sejak awal bisa mengadakan perbaikan yang mendukung kelancaran pencapaian tujuan program.

Evaluasi sumatif dilaksanakan sesudah program berakhir. Dimana tujuan awal evaluasi sumatif ialah buat mengukur keberhasilan suatu program. Kegunaan evaluasi sumatif pada evaluasi kegiatan pembelajaran ditujukan menjadi sarana untuk mengetahui tempat atau kedudukan individu didalam populasinya. Mengingat bahwa objek target dan saat aplikasi tidak sinkron antar evaluasi formatif dan sumatif, dengan demikian lingkup target yang dinilai pula tidak sinkron (Syarifuddin 2016).

Sejalan dengan uraian diatas, evaluasi formatif merupakan evaluasi yang diberikan agar mengetahui hasil belajar yang diraih siswa, sesudah siswa merampungkan program pada tingkat pelajaran tertentu. 
Sedangkan evaluasi sumatif artinya evaluasi yang diberikan sesudah melewati pelajaran dalam satu semester, atau akhir tahun ajaran baru.

\section{Countenance Evaluation Model}

Model Evaluasi penilaian digembalakan Stake. Penilaian untuk mendorong masalah utama, khususnya penggambaran dan pemikiran. Di mana ada tiga kekhawatiran utama yang merupakan item atau fokus penilaian, dan untuk evaluator harus memiliki pilihan untuk mengenali: (1) pendahulu - diuraikan untuk pengaturan (2) pertukaran - diuraikan untuki siklus, (3) Hasil - akan dijadikan hasil akhir.

Model countenance merupakan model evaluasi yang mempunyai unsur hasil dari penggunaan suatu teori. Evaluasi hasil berdasarkan pada unsur hasil belajar yang ada. Kriteria hasil belajar yang biasanya dipakai ialah hasil belajar oleh Benjamin Bloom dkk yang populer dengan Taxonomy Bloom, yakni kemampuan kognitif, afektif dan psikomotorik peserta didik.

\section{Manfaat Model Countenance}

1) Menwawarkan ulasan yang lengkap terhadap suatu program, mulai dari awal penggunaan sampai pada hasil akhir.

2) Komprehensif dalam memfilter data.

3) Keberadaan perhitungan terhadap standar, memberikan efek baik kepada evaluasi yaiyu: evaluasi dapat menggambarkan ketercapaian standar yang telah ditetapkan.

4) Dengan adanya kolaborasi dengan bebrapa ahli, evaluator akan tahu tentang faktor-faktor atau kendala yang mempengaruhi ketercapaian program (Bachtiar 2016).

\section{Model Sepuluh langkah dalam Penilaian}

Evaluasi ini mencakup 10 tahap. Datang berikutnya dinyatakan dalam 10 tahap Penilaian (TenBrink 1974) :

1. Untuk menentukan pilihan yang tepat dan jelas

Dibuat tergantung pada ujung yang tepat, dan tujuan dibuat tergantung pada informasi penting Anda. Membentuk keputusan akhir, memutuskan, kumpulkan, kemudian pada saat itu adalah hal yang dikatakan interaksi penilaian. Dalam menentukan pilihan yang tepat perlu pertimbangan yang mendalam atas benefit dan tujuan yang akan dicapai. Pertimbangan ini dibarengi dengan pencarian invormasi terbaru dan akurat yang dapat diperoleh dari berbagai sumber. Pemilihan model evaluasi haruslah tepat dengan pertimbangan karakteristik siswa yang muncul pada suatu kegiatan belajar mengajar guna untuk mencapai tujuan pembelajaran secara maksimal (Aprida 2017).

2. Data deskribsikan diperlukan Semakin tepat

Deskribsi informasi diperlukan tepat penentuan langkah perangkat agar bisa mengumpulkan data, dan semakin tepat informasi yang valid. Setelah merumuskan pilihan, maka pilihan tersebut perlu dideskribsikan secara tepat. Kegiatan ini bertujuan untuk memberikan arah dan penuntut saat penggunaan model evaluasi yangakan digunakan . Mengumpulkan informasi yang valid agar model evaluasi pendidikan dapat diimplementasikan dengan baik.

3. Data yang diperoleh secara konsisten

Data juga dipergunakan saat memilih, dan dapat dibayangkan bahwa informasi yang didapatkan berbagai informasi penyelenggara dipergunakan oleh instruktur untuk menyelesaikan pilihan akhir dan sesudahnya. Oleh karena itu ketika data gratis, dan jenis data yang diperlukan, dan itu mungkin tepat untuk digunakan (Arikunto 2007). Memperoleh data yang valid dilihat melalui kekonsistenan data yang diperoleh. Data tidak timpang tindih atau besar perubahannya dalam satu waktu (Kadir 2015).

4. Mengumpulkan data harus diperbuat sesuai dengan fakta 
Dapat dibayangkan bahwa berbagai informasi perubahan skedul untuk mengumpulkan informasi. Skedul harus dinyatakan secara eksplisit kapan sesuai seperti apa data akan diperoleh. Data yang dituangkan dalam evaluasi pendidikan haruslah sesuai yang terjadi di dalam kegiatan belajar. Apa yang terjadi dalam penggunaan model evaluasi pendidikan, maka harus itu pula yang dituankan dalam proses pengumpulan data. Adanya kesenjangan antara teori dengan lapangan sering terjadi dan perlu dilakukan revisi mendalam untuk meminimalisir kesenjangan tersebut.

5. Pemilihan instrument data yang akan digunakan.

Membangun atau memilih alat pengumpulan data untuk digunakan di instruktur wali kelas ada suatu tempat di sekitar empat informasi yang sekarang dapat diakses. Informasi dapat sebagai hasil tes, meminta hasil, hasil persepsi, dan melakukan tugas dari siswa. Meskipun demikian, pilihan / perakitan atau kesiapan instrumen harus dipertimbangkan. Banyak hal yang harus dipertimbangkan sebagai alasan untuk penentuan / pengembangan instrumen (Arikunto 2010). Kontemplasi menggabungkan (1) kesamaan dengan motivasi di balik evaluasi, (2) kongruitas dengan ujung-ujung yang harus dibuat, (3) Kesesuaian dengan informasi yang diperlukan. Mengingat berbagai informasi yang berbeda ini tidak diatur dalam prosedur pengumpulan informasi batu seperti melakukan pemeriksaan, penilaian skala yang berbeda, yang semuanya digunakan untuk memperhatikan atau menguji.

6. Dalam langkah pengumpulan informasi ini

Klarifikasi pedoman penggunaan setiap metode pengumpulan data dan informasi. Dalam pelaksanaan pengumpulan data, hal utama yang harus dilakukan instruktur adalah memahami petunjuk yang disusun pada desain instrumen yang dibuat pada langkah kelima. Pada tahap ini perlu adanya sintak atau pedoman yang digunakan pendidik untuk menyususn instrumen yang kelak akan digunakan sebagai alat memperoleh data atau informasi. Instrumen yang digunakan hendaknya disusun melalui kompetensi yang relevan sehingga instrumen tersebut dapat menghasilkan informasi yang faktual dalam melihat efektifitas penggunaan suatu model evaluasi pendidikan (Sudjono 2011).

7. Setelah data dikumpulkan atau diperoleh.

Dalam proses ini pendidik harus membedah data. Dari efek samping membedah data dibuat berakhir yang dengan demikian hanya diputuskan. Membedah data maksudnya mongolah data dengan perhitungan-perhitungan yang sesuai dengan penggunaan model evaluasi pendidikan dalam suatu kegiatan belajar. Mengolah data brtujuan untuk memperoleh da6ta yang valid dan reliabel (Sumarna Surapranata 2006).

8. Untuk membingkai ujung dapat digunakan nilai,

Konsekuensi dari persepsi yang telah rusak sinkron 7. Metode yang paling efektif untuk membentuk ujung dapat dengan kontras ujung yang penilaian, harapkan dapat dibuat. Setelah mengolah data diperlukan muara akhir dari pengolahan tersebut sebelum membuat sebuah keputusan.

9. Buat Keputusan

Menyelesaikan pilihan lebih membingungkan daripada membuat berakhir. Kualitas dari ujung yang dibuat oleh instruktur harus memenuhi standar: Sederhana, Fleksibel, dan Objektif. Dasar: itu berarti tidak sulit untuk menyelesaikannya, tidak membutuhkan banyak waktu, dan mudah (Lina 2010). Kemampuan beradaptasi menguntungkan untuk pilihan kompleks, yang berisi beberapa pilihan lain. Kemampuan beradaptasi menguntungkan untuk pilihan kompleks, yang berisi beberapa pilihan lain. Pengambilan keputusan harus berdasarkan fakta lapangan dan kesesuaian serta ketercapaian subjek penilaian.

10.Laporan

Laporan evaluasi adalah gerakan untuk memperjelas peningkatan bagian-bagian perkembangan dan kemajuan yang telah diklaim oleh anak-anak dalam waktu tertentu. (Purwanto 2009). Laporan evaluasi ini akan menggambarkan seluruh hasil yang diperoleh dari penggunaan model evaluasi pendidilkan. 
Apabila laporan evaluasi menggambarkan ketidaktercapaian tujuan penilaian maka perlu dilakukan revisi ulang. Bisa saja ini terjadi karena kurang tepat dalam memilih model evaluasi atau belum sempurna dalam pelaksanaan model tersebut. Dengan adanya revisi dan melalui pertimbangan kesalahan sebelumnya, maka akan timbul pemilihan dan pelaksanaan model evaluasi pendidikan yang lebih baik sehingga tujuan penilaian tercapai demgan baik.

\section{KESIMPULAN}

Pelatihan adalah program yang terdiri dari beberapa bagian yang bekerja dalam kerangka kerja. Program ini adalah tindakan yang akan dilakukan dengan mengatur dan tujuan yang harus dicapai. Sebagai program instruktif memerlukan penilaian untuk memeriksa apakah tujuan yang diatur program dapat diketahui. Model penilaian instruksi adalah model atau contoh referensi interaksi evaluasi dalam membedah dan mengumpulkan untuk memutuskan tingkat kemajuan suatu tindakan dalam pelatihan untuk mengatur pencapaian tujuan bagi kedua guru dan siswa. Penilaian instruktif tidak dapat diisolasi dari proses pendidikan dan pembelajaran. Dari latihan penilaian akan tampak energi dan kekuatan yang ada pada saat pembelajaran terjadi. Jika tidak ada makanan, penilaian ide atau program pendidikan yang telah diterapkan. Evalusion instruktif seharusnya efektif dengan asumsi ada peningkatan atau peningkatan intelektual, penuh perasaan dan psikomotor.

\section{UCAPAN TERIMA KASIH}

Terimakasih banyak kepada Anda untuk berbagai pertemuan yang telah membantu analisis dalam menyelesaaikan artikel ini dengan tujuan bahwa artikel ini dapat diakui dan dapat menjadi aturan bagi ilmuwan yang berbeda dalam mengarahkan eksplorasi.

\section{DAFTAR PUSTAKA}

Amri, Sofan. 2015. Pengembangan Dan Model Pembelajaran Dalam Kurikulum 2013. Jakarta: Prestasi Pustaka.

Aprida, Pane. 2017. "Belajar Dan Pembelajaran.” Fitrah Jurnal Kajian Ilmu-Ilmu Keislaman Volume 03,

Arif, Muhammad Toriqul. 2019. "Penelitian Evaluiasi Pendidikan.” Addabana Jurnal Pendidikan Agama Islam 2.

Arifin, Zainal. 2014. Evaluasi Pembelajaran. Bandung: Pt Remaja Rosdakarya.

Arikunto, Suharsimi. 2007. Dasar-Dasar Evaluasi Pendidikan. Jakarta: Bumi Aksara.

- 2010. Evaluasi Program Pendidikan. Pedoman Teoretis Praktis Bagi Praktis Pendidikan. Jakarta: Bumi Aksara.

Bachtiar, Rayendra Wahyu. 2016. "Model Evaluasi Countenance Stake Menggunakan Pendekatan Analisis Rasch Terhadap Keterampilan Pemecahan Masalah Kolaboratif." Unej 2.

Darodjat D, Wahyudhiana W. 2015. "Model Evaluasi Program Pendidikan.” Jurnal Pemikiran Islam 14.

Desi, Anwar. 2002. Kamus Bahasa Indonesia Modern. 1st Ed. Ed. Amelia. Surabaya: Amelia.

Elis Ratna Wulan, Elis And Rusdiana, A. 2015. Evaluasi Pendidikan. Bandung: Pustaka Setia.

Fortuna, And Yanti Fitria. 2021. "Upaya Meningkatkan Literasi Sains Siswa Sekolah Dasar Dalam Pembelajaran Daring Akibat Covid19." Basic Edu 5: 2054-61.

Hamalik, Oemar. 2011. Pengembangan Kurikulum. Bandung: Remaja Rosdakarya. 
Kadir, Abdul. 2015. "Menyusun Dan Menganalisis Tes Hasil Belajar.” Jurnal Al-Ta'dib 8: 75.

Kunandar. 2013. Penilaian Autentik (Penilaian Hasil Belajar Peserta Didik Berdasarkan Kurikulum. Jakarta: Rajawali Pers.

Lina, Neneng. 2010. Perencanaan Pendidikan. Bandung: Pustaka Setia.

Mahmudi, Ihwan. 2011. “Cipp: Suatu Model Evaluasi Program Pendidikan.” Journal Of Pesantran Education 6.

Mutiaramses, Mutiaramses, Neviyarni S, And Ida Murni. 2021. "Eran Guru Dalam Pengelolaan Kelas Terhadap Hasil Belajar Siswa Sekolah Dasa." Pendas: Jurnal Ilmiah Pendidikan Dasar 6(Doi: 10.23969/Jp.V6i1.4050.).

Nizar, Ahmad Rangkuti. 2016. Metode Penelitian Pendidikan Pendekatan Kuantitatif, Kualitatif, Ptk, Dan Penelitian Pengembangan. Bandung: Citapustaka Media.

Pratiwi Pujiastuti, Sekar Purbarini Kawuryan, Dan Unik Ambarwati. 2017. "Evaluasi Pembelajaran Tematik Di Sekolah Dasar." Jurnal Kependidikan Volume 1.

Purwanto. 2009. Evaluasi Hasil Belajar. Bandung: Pustaka Pelajar.

Putra, Aris Try Andreas. 2014. "Evaluasi Program Pendidikan: 'Pedekatan Evaluasi Program Berorientasi Tujuan (Goal-Oriented Evaluation Approach: Ralph W. Tyler)." Jurnal Profit 2.

Rina Novalinda, Ambiyar, Fahmi Rizal. 2020. "Pendekatan Evaluasi Program Tyler: Goal-Oriented." Edukasi: Jurnal Pendidikan 18 No 1.

Siregar, And Harahap N. 2019. Strategi Dan Teknik Penulisan Karya Tulis Ilmiah Dan Publikasi. Sleman: Deepublish.

Sudjono, Anas. 2011. Pengantar Evaluasi Pendidikan. Jakarta: Raja Grafindo Persada.

Sumarna Surapranata. 2006. Analisis, Validitas, Reliabilitas Dan Interpretasi Hasil Tes Implementasi Kurikulum 2004. Bandung: Pt Remaja Rosdakarya.

Syarifuddin, Mardiah \&. 2016. "Model-Model Evaluasi Pendidikan." Jurnal Pendidikan \& Konseling Volume 2.

Synder. 2019. "Literature Review As A Research Methodology: An Overview And Guidelines." Journal Of Business Research 104 333-33.

Tenbrink, Terri D. 1974. Evaluation:A Practical Guide For Teachers. Amerika: Mcgraw-Hill.

Yuwono, Imam, And Mirnawati. 2021. "Strategi Pembelajaran Kreatif Dalam Pendidikan Inklusi Di Jenjang Sekolah Dasar." Jurnal Basicedu. 